Jap. J. M. Sc. \& Biol., 14, 257-262, 1961

\title{
A BRIEF SURVEY OF PARASITIC HELMINTH IN SOUTH LAOS AND CAMBODIA WITH A COMPARISON TO THE STATE IN THAILAND
}

\author{
JIRO ITO \\ Hygiene Laboratory, Shizuoka University, Japan \\ SUJARTI JATANASEN \\ Ministry of Public Health, Thailand
}

(Received: October 30th, 1961)

Whereas the epidemiologic study of parasitic helminth in Thailand have been reported by several authors, that of Laos and Cambodia is little known at present. We have an opportunity of visiting South Laos and Cambodia along Mekong River Basin in order to make a survey on schistosomiasis in 1960. During the staying period of one and a half months in that region, our survey was focused on three subjects; seeking a susceptible intermediate snail host of Schistosoma japonicum, intradermal skin test of schistosomiasis on the inhabitants, and stool examination of the inhabitants.

As far as the schistosomiasis japonica is concerned, no trace of the existence of that disease was detected. This was already reported by us as an assignment report, WPRO 80, from the regional office of WHO in August, 1960. On the other hand it was revealed by the stool examination that a remarkably high incidence of intestinal helminth among the rural people was observed. So this is a report concerning mainly that incidence of intestinal helminth in the region of our short time examination.

\section{Description of the AREAs SuRveyed}

Four cities were selected as our survey stations, namely, Pakse in Laos, Stungtreng, Kompong-Cham, and Siemleap in Cambodia.

Pakse, population of ca. 26,000 people, is the second large city of Laos situated at the bank of the Mekong where the Sedone River joins the Mekong. Our main effort of examination was directed to the islanders of Done Deng Island and Done Kho Island in the Mekong River near Pakse. Suburban farmers were also examined. Rice, banana, and coconut are main farm products. The economic situation is rather poor as a whole. Water supply, sewage and refuse disposal are not organized and are operated on an individual basis. Rain water is the only source of drinking water.

Stungtreng, population of ca. 5,000 people, is a small city of Cambodia, situated along the Mekong River where the Sekong River joins the Mekong. This city is surrounded by a dense jungle, and the communication with the village is too inconvenient to visit by car. Small rice pad and several fruit trees are farmers' only property. 
Most of them are poor and have little knowledge on their health.

Kompong-Cham, population of ca. 26,000 people, on the bank of Mekong, is approximately 100 kilometers far from Phnompenh. This city looks like so rich, being more beautiful and in better sanitary condition than the other cities surveyed. Suburban farmers are also rather rich, furnished with a large rice pad property. Several big rubber forests are near this city. But the sanitary condition in rural areas are not so good. Water supply, sewage and refuse disposal are also poorly organized.

Siemleap is a famous city near the Lake Tonle Sap, because of the existence of the ruin, Angkor Wat. Many foreign travellers used to stay here to visit the Angkor Wat. General condition of this area is rather as good as that of Kompong-Cham.

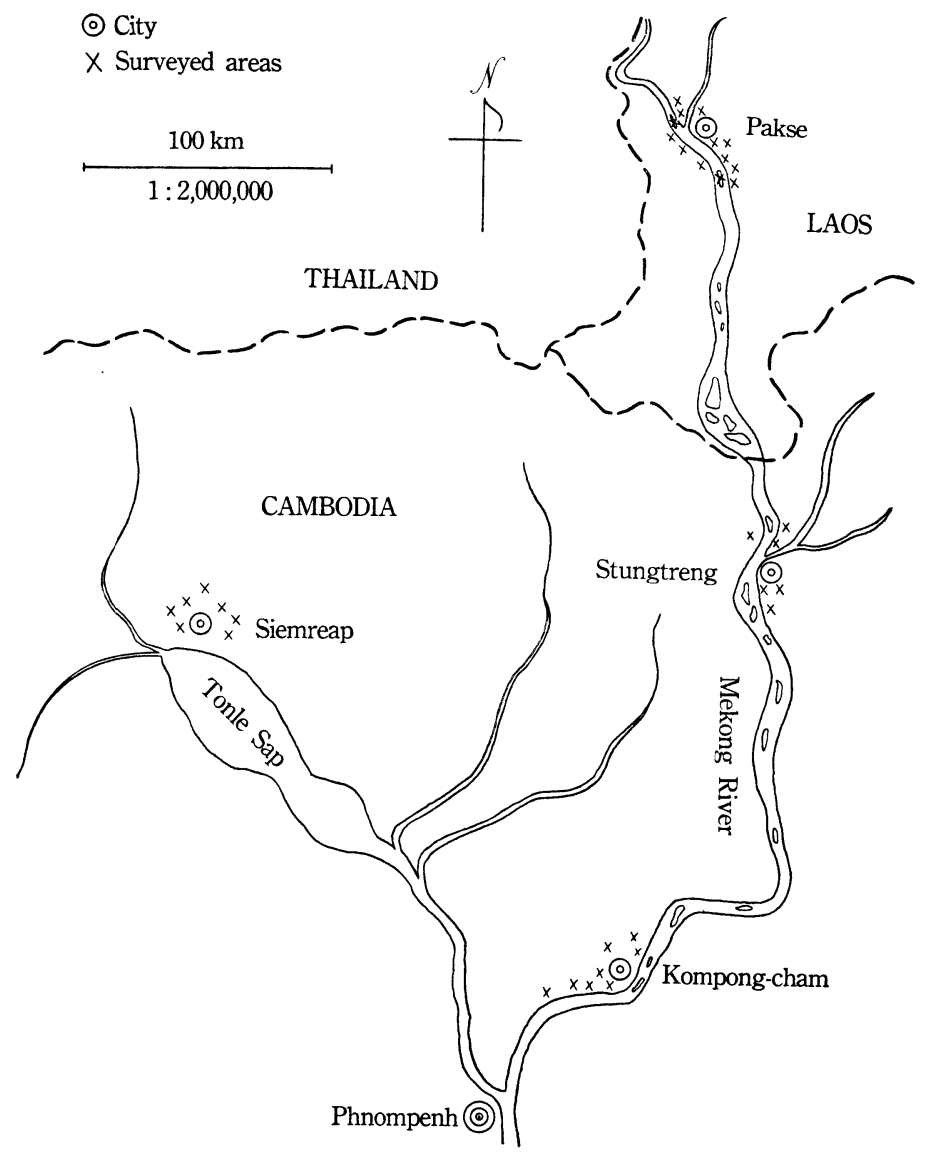

Fig. 1. General map of surveyed area.

\section{MATERIALS AND METHODS}

One of our main efforts was directed to establish the presence of an intermediate snail host of Schistosoma japonicum. So snails were collected from the water areas such as rice pad, lake, pond, canal, stream, ditch, etc.

As to the intradermal skin test of $S$. japonicum, the antigen was made from the adult worm 
of Schistosoma japonicum in Japan. Fifteen minutes after injection on the forearm of farmers in every village, the degree of swelling was observed. If the swelling area of the skin was twice the size of that originally caused by intradermal injection, the case was considered positive.

After finishing the intradermal skin test, the collection of their own feces was emphatically asked to all members of every village. Unfortunately only a few materials could be obtained in each village. Because of a meagre equipment and a limited time, the stool examination was done by direct smear method of unstains only.

\section{RESULTS}

The localities of collecting snails are summarized in Table 1. All of these snails were identified by Dr. Kuroda in Kyoto University. Vivipariidae, such as Viviparus filosus, V. (Taia) ingallsiana, Sinotaia trochoides, S. subciliata, Pila (Turbinicola)

Table 1. Localities of the collecting snails

\begin{tabular}{|c|c|c|c|c|c|c|c|}
\hline Province & Locality & Date & $\underset{\text { dae }}{\text { Melanii- }}$ & $\begin{array}{l}\text { Bithynii- } \\
\text { dae }\end{array}$ & $\begin{array}{l}\text { Viviparii- } \\
\text { dae }\end{array}$ & $\begin{array}{c}\text { Planorbii- } \\
\text { dae }\end{array}$ & $\underset{\text { dae }}{\text { Lymnaei- }}$ \\
\hline \multirow{8}{*}{ Paksé } & Ban Nahek & 17 June & (A) stream & (VR) ricepad & - & - & - \\
\hline & Done Déng & 18 June & - & - & (C) rice pad & - & - \\
\hline & Done Kho & 20 June & - & (VR) ricepad & (C) rice pad & (C) pond & - \\
\hline & Paksé & 21 June & - & - & - & - & - \\
\hline & Done Déng & 22 June & - & - & - & (R) ditch & - \\
\hline & Done Kho & 25 June & - & - & (C) rice pad & (C) pond & - \\
\hline & Paksé & 27 June & - & (C) pond & (C) pond & (A) pond & - \\
\hline & Done Khō & 5 July & - & - & (C) rice pad & - & - \\
\hline \multirow{3}{*}{$\begin{array}{l}\text { Stung- } \\
\text { treng }\end{array}$} & (Kan Kusang & 14 July & - & (C) lake & (C) lake & - & - \\
\hline & $\{$ Surai Rusai & 15 July & - & - & (C) ditch & - & (C) ditch \\
\hline & Kan Daisar & 16 July & - & (C) canal & (C) canal & (C) canal & - \\
\hline \multirow{4}{*}{$\begin{array}{l}\text { Kompong- } \\
\text { cham }\end{array}$} & Ban Roan & 19 July & (A) lake & (A) lake & (A) lake & - & - \\
\hline & Chong Kos Samrong & 19 July & (C) lake & (A) lake & (C) lake & - & - \\
\hline & Svay-Méas & 20 July & (C) lake & (A) lake & (C) lake & - & - \\
\hline & (Peam Chikang & 21 July & (C) lake & (A) lake & (A) lake & - & (C) lake \\
\hline \multirow{5}{*}{$\begin{array}{l}\text { Siemreap } \\
\& \text { the } \\
\text { Others }\end{array}$} & ( Poluos & 25 July & - & - & (A) pond & - & - \\
\hline & Puok & 26 July & - & - & (A) pond & (R) pond & - \\
\hline & Nokor Thom & 27 July & - & - & (A) pond & - & - \\
\hline & Thoren & 29 July & - & (C) lake & - & - & - \\
\hline & Svay Daunkeo & 30 July & (R) lake & (C) lake & (A) lake & - & - \\
\hline
\end{tabular}

Abreviation: (VR) very rare, (R) rare, (C) common, (A) abundant.

polita, and Pila (Turbinicola) conica, were most abundant at every place. Another main species were as follows; Melaniidae such as Stenomelania brunnescens, S. schomburgki, Melanoides tuberculatus, and Clea (Anentome) baudoniana; Bithyniidae such as Digoniostoma funiculata and Wattebledia crosseana; Planorbiidae such as Indoplanorbis exustus, Gyraulus convexiusculus and Hippeutis umbilicalis; and Lymnaeidae such as Lymnaea (Radix) auricularia rubiginosa. No Oncomelania spp. was found as far as we surveyed in the area,

Table 2 shows the result of intradermal skin test of $S$. japonicum. Among 1,514 people examined in Laos and Cambodia, only three positive cases were observed, but these cases were considered to be false ones.

In spite of a great effort of collecting the fecal specimens, only 292 specimens could be examined in both countries. Though protozoan parasites such as Entamoeba, Trichomonas, Giardia, etc., were detected occasionally, but those data were omitted here 
Table 2. Intradermal skin test of $S$. japonicum for the inhabitants.

(20 June - 28 July, 1960)

\begin{tabular}{|c|c|c|c|c|c|}
\hline Province & Village & $\begin{array}{l}\text { Number of } \\
\text { tested }\end{array}$ & $\begin{array}{l}\text { Number of } \\
\text { positive }\end{array}$ & $\begin{array}{l}\text { Number of } \\
\text { doubtful }\end{array}$ & $\begin{array}{l}\text { Number of } \\
\text { negative }\end{array}$ \\
\hline Paksé & $\begin{array}{l}\text { B. Done Kho } \\
\text { B. Saphay } \\
\text { Done Déng } \\
\text { B. Done Khō } \\
\text { B. Yong } \\
\text { Hospital } \\
\text { total }\end{array}$ & $\begin{array}{r}51 \\
82 \\
310 \\
168 \\
138 \\
53 \\
802\end{array}$ & $\begin{array}{l}0 \\
0 \\
1 \\
0 \\
0 \\
1 \\
2(0,2 \%)\end{array}$ & $\begin{array}{l}1 \\
1 \\
6 \\
2 \\
1 \\
1 \\
12\left(1-50^{\circ}\right)\end{array}$ & $\begin{array}{r}50 \\
81 \\
303 \\
166 \\
137 \\
51 \\
788\end{array}$ \\
\hline Stungtreng & $\left\{\begin{array}{l}\text { Kan Kusang } \\
\text { Surai Rusai } \\
\text { Kan Daisar } \\
\text { Hospital } \\
\quad \text { total }\end{array}\right.$ & $\begin{array}{r}125 \\
28 \\
50 \\
8 \\
211\end{array}$ & $\begin{array}{l}0 \\
0 \\
0 \\
0 \\
0\end{array}$ & $\begin{array}{l}0 \\
0 \\
2 \\
0 \\
2(1.0 \%)\end{array}$ & $\begin{array}{r}125 \\
28 \\
48 \\
8 \\
209\end{array}$ \\
\hline $\begin{array}{l}\text { Kompong- } \\
\text { Cham }\end{array}$ & $\begin{array}{l}\text { Bang Roang } \\
\text { Sambour-Meas } \\
\text { Svay-Méas } \\
\text { Peam Chikang } \\
\text { Hospital } \\
\text { total }\end{array}$ & $\begin{array}{r}106 \\
43 \\
35 \\
56 \\
61 \\
301\end{array}$ & $\begin{array}{l}0 \\
0 \\
0 \\
0 \\
1 \\
1(0.3 \%)\end{array}$ & $\begin{array}{l}0 \\
0 \\
0 \\
0 \\
0 \\
0\end{array}$ & $\begin{array}{r}106 \\
43 \\
35 \\
56 \\
60 \\
300\end{array}$ \\
\hline Siemreap & $\begin{array}{l}\text { Poluos } \\
\text { Puok } \\
\text { Nokor Thom } \\
\text { Hospital } \\
\quad \text { total }\end{array}$ & $\begin{array}{r}52 \\
59 \\
52 \\
37 \\
200\end{array}$ & $\begin{array}{l}0 \\
0 \\
0 \\
0 \\
0\end{array}$ & $\begin{array}{l}0 \\
0 \\
0 \\
0 \\
0\end{array}$ & $\begin{array}{r}52 \\
59 \\
52 \\
37 \\
200\end{array}$ \\
\hline \multicolumn{2}{|c|}{ Total in Cambodia } & 712 & $1(0.1 \%)$ & $2(0.3 \%)$ & 709 \\
\hline All totals & & 1514 & $* 3(0.2 \%)$ & $* 14(1.0 \%)$ & 1497 \\
\hline
\end{tabular}

* All of these cases were considered to be false ones.

because of lacking their accuracy. The infection rate of helminth in both countries is given in Table 3 .

In Laos, main species of helminthic parasites were Ascaris, hook worm, whip worm and liver fluke. It was noticeable that liver fluke (Opisthorchis viverrini) infection was so heavy that numerous eggs were easily observed in most of the cases. If detailed examination was carried out by concentration method, the infection rate of liver fluke must be increased remarkably. Taenia saginata infection was also frequently observed, sometimes by the segments and sometimes by the eggs.

In Cambodia, liver fluke and tape worm infection could not be detected. On the other hand the incidence of ascaris and hook worm infection were very high. Especially in the case of hook worm, approximately $50 \%$ of infection rate was revealed by simple smear method only. The accurate infection rate of hook worm should be much higher than the present result.

\section{DISCUSSION}

The latitude level of South Laos is nearly the same as that of North Thai, and that of Cambodia corresponds to that of Central and South Thai. According to Vajrasthira 
Table 3. Fecal examination in Laos and Cambodia by simple smear method (23 June-28 July, 1960)

\begin{tabular}{|c|c|c|c|c|c|c|c|c|c|c|c|}
\hline \multirow{2}{*}{$\begin{array}{l}\text { Count- } \\
\text { ries }\end{array}$} & \multirow[b]{2}{*}{ Village } & \multirow{2}{*}{$\begin{array}{c}\text { Num- } \\
\text { ber of } \\
\text { ex- } \\
\text { amined }\end{array}$} & \multirow{2}{*}{$\begin{array}{l}\text { Num- } \\
\text { ber of } \\
\text { positi- } \\
\text { ve }(\%)\end{array}$} & \multicolumn{8}{|c|}{ Helminths Found } \\
\hline & & & & $\begin{array}{l}\text { Schi- } \\
\text { sto- } \\
\text { soma }\end{array}$ & $\begin{array}{c}\text { Ascaris } \\
\text { lumbrico- } \\
\text { ides }\end{array}$ & $\begin{array}{l}\text { Hook } \\
\text { worm }\end{array}$ & $\begin{array}{l}\text { Tricho- } \\
\text { cepha- } \\
\text { lus }\end{array}$ & $\begin{array}{l}\text { Liver } \\
\text { fluke }\end{array}$ & $\begin{array}{l}\text { Taenia } \\
\text { sagi- } \\
\text { nata }\end{array}$ & $\begin{array}{l}\text { Stron- } \\
\text { gyloi- } \\
\text { des }\end{array}$ & $\begin{array}{c}\text { Entero- } \\
\text { vius }\end{array}$ \\
\hline \multirow{6}{*}{ Loas } & Done Deng & 43 & $34(70.1)$ & 0 & $25(58.1)$ & $14(32.6)$ & $8(18.6)$ & $11(25.6)$ & 0 & 0 & 0 \\
\hline & Done Kho & 16 & $9(56.3)$ & 0 & $3(18.8)$ & $3(18.8)$ & $4(25.0)$ & $2(12.5)$ & 0 & 0 & 0 \\
\hline & Done Khō & 51 & $36(70.6)$ & 0 & $16(31.3)$ & $20(39.2)$ & $2(3.9)$ & $7(13.7)$ & $1(2.0)$ & 0 & $2(3.9)$ \\
\hline & Ban Yong & 18 & $15(83.3)$ & 0 & $10(55.6)$ & $5(27.8)$ & $1(5.6)$ & $1(5.6)$ & 0 & $1(5.6)$ & 0 \\
\hline & Hospital & 30 & $16(56.7)$ & 0 & $10(33.3)$ & $6(20.0)$ & $6(20.0)$ & 0 & $1(3.3)$ & 0 & 0 \\
\hline & Total & 1581 & $110(72.2)$ & 0 & $64(40.5)$ & $48(30.4)$ & $21(13.3)$ & $21(13.3)$ & $2(1.3)$ & $1(0.6)$ & $2(1.3)$ \\
\hline \multirow{7}{*}{ bam- } & Roan & 15 & $12(80.0)$ & 0 & $9(60.0)$ & $7(46.7)$ & 0 & 0 & 0 & 0 & 0 \\
\hline & $\begin{array}{l}\text { Hospital in } \\
\text { Kg-Chem }\end{array}$ & 31 & $22(71.0)$ & 0 & $11(35.5)$ & $17(54.8)$ & 0 & 0 & 0 & $1(3.2)$ & 0 \\
\hline & Poluos & 16 & $14(87.5)$ & 0 & $9(58.3)$ & $7(45.8)$ & 0 & 0 & 0 & $1(6.3)$ & 0 \\
\hline & Puok & 21 & $8(38.1)$ & 0 & $3(14.3)$ & $6(28.5)$ & 0 & 0 & 0 & 0 & 0 \\
\hline & Nokor Thom & 18 & $15(83.3)$ & 0 & $5(27.8)$ & $12(66.7)$ & 0 & 0 & 0 & 0 & 0 \\
\hline & $\begin{array}{l}\text { Hospital in } \\
\text { Siemreap }\end{array}$ & 33 & $21(63.6)$ & 0 & $9(27.3)$ & $16(48.5)$ & 0 & 0 & 0 & $1(3.0)$ & 0 \\
\hline & Total & 134 & $92(68.6)$ & 0 & $46(34.3)$ & $65(48.5)$ & 0 & 0 & 0 & $3(2.2)$ & 0 \\
\hline
\end{tabular}

Note: It is realized that the figures above are not statistically significant in view of the small number examined.

and Harinasuta (1957), the incidence of helminth in North-East Thai is as follows; Ascaris $7.5 \%$, hook worm $19.5 \%$, whip worm $2.4 \%$, Strongyloides $1.2 \%$, Taenia $3.4 \%$ and liver fluke (Opisthorchis viverrini) 29.8\%. These figures nearly resembled the present result of South Laos. As to the liver fluke infection in Thai, Harinasuta (1960) pointed out three factors of the prevalence, the habit of consuming raw fish food, defecation on the ground due to lack of latrine and the prevalence of susceptible intermediate hosts. This may be just similar condition concerning the prevalence of liver fluke infection in Laos. The prevertion of liver fluke infection is mainly dependent on changing the custom of eating raw fish by health education for the people. Then Laos, and also Thailand, can wipe out the reproach of the highest endemic area of liver fluke in the world.

The terrible dense prevalence of hook worm infection in Cambodia may be one of the urgent problems of sanitary administration. Many climatological conditions are responsible for the spread out of such remarkable hook worm incidences. Abundant rainfall all over the year, nearly constant temperature and humidity, good shades from rubber plantation and fruit orchard may support the development of hook worm ova into the infective larvae. The settlement of latrine in each house and prohibition of barefoot walking should be main control schedule. These condition in Cambodia is also similar to that in South Thai, as well as perhaps in South Vietnam and Malaya, etc.

\section{SUMMARY}

A brief survey of schistosomiasis japonica, as well as parasitic helminth, along the Mekong River Basin was carried out. As to the schistosomiasis japonica, no patient or no intermediate snail host could be detected as far as we surveyed. On the other hand, a remarkably high incidence of intestinal helminth was revealed by fecal exami- 
nations. Especially liver fluke infection in South Laos and hook worm infection in Cambodia seemed to be a serious administrative problem. With a comparison to the state in Thailand, it is presumable that the northern part of this peninsula is a high endemic area of Opisthorchis viverrini, while on the contrary the southern part of this peninsula is a high endemic area of hook worm.

The authors wish to acknowledge the management of WHO in giving such an opportunity of survey. Sincere thanks are due to Dr. Tokubei Kuroda (Kyoto University, Japan) for making the identification of snails. Most of our scientific equipment was kindly furnished by Dr. Chamlon Harinasuta (Dean of the Faculty of Tropical Medicine and Hygiene, Bangkok). Everywhere we stayed, many doctors and their co-workers joined us to undertake these surveys and we should like to mention here their names; Dr. Khamleck Vilay (Director-General of Ministry of Health, Laos), Dr. Chantaboun (Chief of Pakse Hospital), Dr. My-Samedy (PhnomPenh Hospital), Dr. Uam-Chhem (Chief of Stungtreng Hospital), Dr. Hun-Sareth (Chief of Kompong-Cham Hospital), Dr. Men-Huon (Chief of Siemleap Hospital) and Dr. Matthias Zeville (WHO staff in Vietnam).

\section{REFERENCES}

Chatyaporn, V., Koonvisal, L. \& Dharamadhach, A. (1959): The first case of schistosomiasis japonica in Thailand. J. M. Assoc. Thailand, 42, 438-441.

HARINASUTA, C. (1960): Studies on helminthic infection in Thailand. 2. The epidemiology of the important helminthes. M. J. Thailand, 9, 27-41.

HARINASUTA, C., \& VAJRAsthiRA, S. (1959) : Study on Opisthorchiasis in Thailand. 1. The incidence of opisthorchiasis in patients of fifteen hospitals in the Northeast. J. M. Assoc. Thailand, 42, 584-598.

Ito, J. \& JATANASEN, S. (1960): Preliminary survey of bilharziasis in South Laos and Cambodia. Assignment report from Regional Office of WHO, WPRO 80, Manila,

VAJRASTHIRA, S. \& HARINASUTA, C. (1957): Studies on helminthic infections in Thailand. 1. Incidence, distribution and epidemiology of seven common intestinal helminths. J. M. Assoc. Thailand, 40, 309-340. 